\section{Young blood heals old muscles}

A ging muscles just don't heal themselves as well as young ones do. Although it is not yet clear why this is so, an abundance of research points to a loss of responsiveness of tissue-specific stem cells as the cause. ${ }^{1}$ New research suggests that although older stem cells do in fact retain their inherent reparative ability, the signals that switch this process on fail with age.

The wear and tear of aging results in the progressive loss of function of tissues and organs. Some stem cells reside in tissues, where they help maintain homeostasis and repair injury. ${ }^{1}$ For instance, skeletal muscle stem cells, called satellite cells, proliferate and develop into myoblasts to regenerate injured muscle. As muscles age, however, these satellite cells lose their ability to proliferate. $^{2}$ Why this occurs is only now being appreciated.

In 2003 Conboy and colleagues ${ }^{3}$ discovered that satellite cells in injured muscle tissue of younger animals increased expression of a surface protein (Delta), while satellite cells of similarly injured older animals did not. These researchers then found that by forcing the older satellite cells to express the Delta protein they were able to restore the ability of aged muscle to regenerate. ${ }^{3}$

These findings raised the question of whether the failure to express the Delta protein was a problem inherent in the aging satellite cells, or resulted from factors affecting the cellular environment.

\section{An infusion of young blood}

The current work by Conboy and colleagues goes a long way toward answering this question. The researchers hypothesized that since aged satellite cells could be coaxed into regenerating muscle, they weren't solely at fault; rather, they found themselves in a repressive environment - an idea that suggests all you need to do is switch the environment from "old" to "young," and stem cells will be "rejuvenated."

To test this hypothesis, Conboy and colleagues paired mice together to share a common circulatory system through vascular anastamoses. Young mice paired with young mice regenerated their muscles normally, while, as expected, old mice paired together did this poorly. In contrast, pairing young mice with old mice significantly improved the regeneration of muscle in the old mice. By using a detectable marker in one of the pair, the researchers were able to confirm that, in old mice paired with young mice, muscle repair was carried out by their pre-existing satellite cells. Consistent with this, the researchers also found that expression of the Delta protein by satellite cells in old mice was restored when they were paired with young mice. ${ }^{4}$

Overall, these new results suggest that aging blood can create a repressive environment in which stem cells regenerate tissue poorly. However, the molecular pathways involved in this decline can be reset, offering hope that therapeutic intervention is possible. This is good news for muscles; between age 30 to 80 over one third of muscle mass is lost. ${ }^{5}$ In addition, aging-associated muscle loss (sarcopenia), which significantly impairs mobility, affects upwards of $25 \%$ of people aged 65 years or older. It may be a Herculean effort to identify youth-

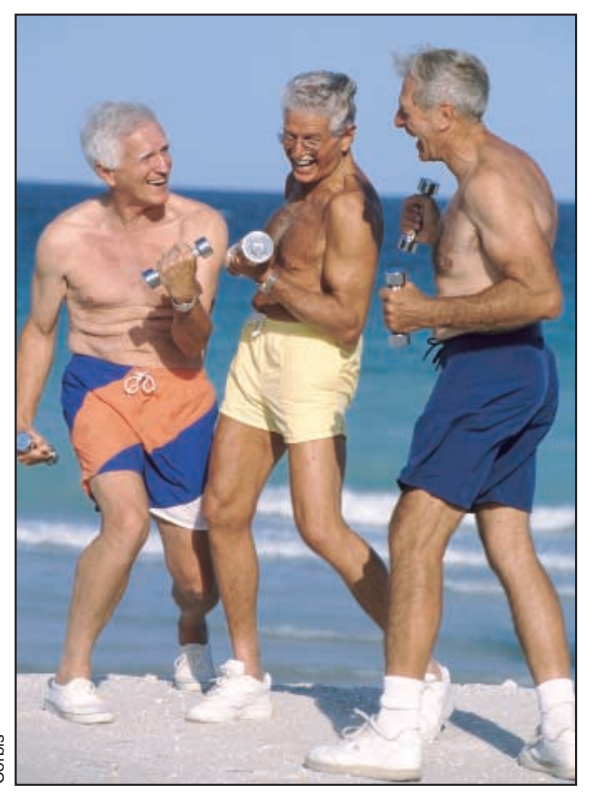

Aging muscles need young blood.

promoting factors in the blood, but accomplishing this feat will will offer therapeutic targets that might one day help everyone's aching muscles. — David Secko, Vancouver

\section{References}

1. Van Zant G, Liang Y. The role of stem cells in aging. Exp Hematol 2003;31(8):659-72.

2. Carlson BM. Muscle regeneration in amphibians and mammals: passing the torch. Dev Dyn 2003;226(2):167-81.

3. Conboy IM, Conboy MJ, Smythe GM, Rando TA. Notch-mediated restoration of regenerative potential to aged muscle. Science 2003;302 (5650):1575-7.

4. Conboy M, Conboy MJ, Wagers AJ, Girma ER, Weissman IL, Rando TA. Rejuvenation of aged progenitor cells by exposure to a young systemic environment. Nature 2005;433:760-4.

5. Miller JB, Emerson CP Jr. Does the road to muscle rejuvenation go through Notch? Sci Aging Knowledge Environ 2003;2003(48):pe34. 